\title{
Issues of shared-equity construction development in the Russian Federation
}

\author{
Vladislav Uskov ${ }^{1 *}$, and Emma Shariapova ${ }^{1}$ \\ ${ }^{1}$ Saint Petersburg State University of Architecture and Civil Engineering, Krasnoarmeyskaya Str., 4, \\ St. Petersburg, $2^{\text {nd }}, 190005$, Russia
}

\begin{abstract}
The leading role of the construction sector is considered toppriority for the development of other sectors of economic activity and consolidation of social stability. The development and competitiveness of the country's economy largely depends on the efficiency of the construction complex functioning. Besides the legislative amendments aimed at protection from real estate scams, it was proposed to create a new system of shared-equity construction. For instance, in 2017, the list of instructions from the President of the Russian Federation was published that summarized the results of the meeting with members of the government. The Government of the Russian Federation, together with the Central Bank of Russia and the Agency of Housing Mortgage Loans, were assigned to develop within three years a legal framework of the staged replacement of citizens' funds attracted for erection of apartment buildings and other real estate with bank lending or other forms of financing. Changes in the legislation of the Russian Federation inevitably lead to new risks emerging in the shared-equity construction. The article presents the analysis of the development of legal relations in shared-equity construction, shows possible ways of development, shortcomings and risks of the construction sector, ways to resolve possible conflicts.
\end{abstract}

\section{Introduction}

Civil engineering is an important part of human activity. Regardless of its long history, civil engineering still takes one of the most significant parts in human life. Shared-equity construction refers to new forms of the construction industry, although it has already significantly developed. The present paper focuses on the development of housing, particularly on the following terms: legal aspects of development, economic substantiation, influence of economic factors on the development of the construction sector.

The lack of proper regulation in shared-equity construction may lead to the increase in risks of occurring new fraud schemes and to growth of a number of defrauded homebuyers. Lack of control over the situation can make it worse, which will cause negative consequences for the construction market, which in turn can disturb the state's economy. The government adequately assesses the mentioned risks; therefore, in 2019 new rules in the market of shared-equity construction are being introduced. Change in the legislation

\footnotetext{
* Corresponding author: vladuskov@yandex.ru
} 
involves the significant change in the financing scheme for the housing sector of the construction industry. Evaluation and analysis of new rules of share-equity construction will allow pre-determining shortcomings of this system, possible consequences of the new rules' influence directly on a developer, an equity holder and a partner bank of a construction company.

The human right for housing is enshrined by Art. 40 of the Constitution of the Russian Federation. State power is engaged in the promotion of housing construction and creates the necessary conditions for the realization of the right to housing. The citizens needing shelter are provided with housing for free or for an affordable fee by various housing funds.

\section{Methods and materials}

Shared-equity construction problems with defrauded real estate investors, bankruptcy of developers are relevant in Russia, so this issue of their solution has been raised a lot of times. According to Anton Golovin, the senior supervising prosecutor on the implementation of legislation in economics in Russia, by the time of the interview (3.07.18), there were about 850 troubled objects and the problem of defrauded homebuyers existed in almost 80 regions of the Russian Federation. From 2017 to 2018, General Prosecutor Office revealed approximately 15 thousand law violations. These data indicate the need for the strictest legal regulation of activities in shared-equity construction.

Bankruptcies of large construction companies, such as SU-155 or Urban Group, also indicate the challenges of the situation in shared-equity construction. These companies are large, for example, Urban Group ranked eighth in Russia and second in Moscow in terms of construction volume. These companies had to be sanitized to the government, or otherwise such significant participants in the construction and real estate market could adversely affect the market, so more people could suffer. Another significant indicator of this problem is the total debt of SU-155 assets amounting 315 billion rubles with a total asset value of 204 billion rubles. The rating agency of construction companies undertook a study, which showed that from 2007 to 2018 more than 40 thousand people suffered because of the bankruptcy of developers.

During the president's question-and-answer TV session 2018, Vladimir Putin stated that the shared-equity construction problem should be taken under control. He emphasized the need to resolve and improve regulation in this area. Therefore, since July 1, 2018, the requirements for developers who enter into equity agreements have become tougher, and since July 1, 2019, the conclusion of new equity agreements have become impossible. These measures were introduced to strengthen the control in this area, protect equity holders' funds from fraud, control the number of defrauded equity holders and gradually reduce it.

This significantly reduced the risks for shareholders, in particular:

- Prohibition for developers being registered as rogue suppliers, contractors, performers has entered into force;

- The legislator requires a no criminal record in economics from a head of an organization and a chief accountant;

- New version of the project declaration entered into force as well as prohibition to send it to the authorized body without full payment of share capital;

- Capital requirements for a developer were increased;

- Bank guarantee and escrow account introduction became obligatory;

- Control functions of the relevant authorized bodies were enhanced.

The period from 2018 to 2019 can be considered transitional for shared-equity construction, as far as after 2019 the activity of shared-equity construction is going to be 
tied up only in the participation of financial and credit organizations. Conditions for developers in 2018 were restricted in order to reduce the growth in the number of concluded equity agreements, reduce risks for citizens and for the construction market, ease the pressure on the government dealing with this problem, prepare developers for the transition to a new system of escrow accounts.

Escrow account is a system which implies creating an account for shareholders in a bank, where their investments are transferred. A developer opens a credit line under the account of shareholders at a certain percentage and starts the construction by means of funds received. All the remaining homebuyer's money can be transferred to a developer only after completion of the construction. It is also worth noting that in 2017 in the State Duma of the Russian Federation, the head of the United Russia party's working group on the protection of rights of real estate equity holders reported that there were approximately 130,000 defrauded real estate investors and 936 troubled objects countrywide.

Signing agreements according to the system of escrow accounts is required for developers since July 1, 2019. However, this requirement will firstly target only those developers who will make a construction co-funding agreement with their first homebuyer after July 1, 2019.

These innovations are intended to protect equity holders and their money, as well as to accelerate the transition from shared-equity construction to project financing. However, only the law entered into force will allow estimating the security level and effectiveness of this system. Since the law on obligatory escrow accounts will not be entered immediately, frauds that were committed under conclusion of co-funding agreement will remain possible to commit. Moreover, the imposed strict requirements for developers can reduce the number of organizations operating in this market. This in turn will lead to the decrease in competition and increase in prices for living space, which is unprofitable for a buyer and other construction companies. The issue of banks holding investors' money also remains unresolved. Recalling of the license, fraud in banks with homebuyers' money, lack of bank reserves to return the invested funds: these and some other aspects of the industry require a comprehensive analysis aimed to prevent fraud and deception of shareholders, protect their funds and improve the regulatory system in this area of construction.

The opportunity to use mechanisms for banking design of construction financing with opening escrow accounts, which will contain funds of real estate investors until the construction is completed, may be attended by some bank activity risks. This activity is certainly beneficial to banks due to using funds of equity holders, as well as to receiving interest from the developer's credit line.

The construction sector is one of the most profitable industries in the Russian Federation, yet no less risky for both equity holders and banking companies. Government regulation is being improved, new ways of protecting all participants in this activity are being created.

Laws entered into force on July 1, 2018 are intended to prepare developers, equity holders and banks to changings in the rules of economic activity in the construction industry. In 2019, the use of escrow accounts is becoming mandatory for shared-equity construction. Equity holder's funds ought to be stored in a specialized bank account that becomes available to a developer only after the construction completed and a building commissioned. These conditions create certain positive and negative consequences determining the effectiveness of regulation introduced by legislation.

It will be possible to estimate the actual effectiveness of this innovation only over time, on the basis of real precedents, their amount and precise analysis, by identifying behavior patterns in the selected statistical data of a sample frame. 
However, it is already possible to identify some shortcomings of this system in order to prevent negative moments in the future, to reduce the risks of each participant in sharedequity construction and to create a more transparent and simple for regulation activity area.

The compensation fund for shared-equity construction created to improve the protection of equity holders' funds does not imply sufficient protection. The stated $1.2 \%$ of the total value for each equity construction contract should provide a financial reserve that will allow to complete the construction of a residential building. However, the legislator has provided the law with the restriction on the metric area of apartments. Moreover, the compensation will come from the average-weighted market value per square meter, however, this area should not be more than 120 square meters, which allows concluding that rights of homebuyers purchasing large residential areas are prejudiced. It is worth adding that the problem of deceived homebuyers is not solved this way, since part of their funds was not paid into the insurance fund. To address the issue of the shortage of funds that will be allocated to compensate for financial losses, the fund annually assesses the liabilities and adjusts the rate of contributions made. Though, if such a situation really occurs and the funds are lacking, then with rising of a contribution, prices will grow, which will negatively affect the market.

\section{$3 \quad$ Results}

The first law aimed at resolving this issue is the law of December 30, 2004 No. 124-FZ "On the Participation in the Shared-Equity Construction of Apartment Buildings and Other Real Estate Objects", which entered into force on April 1, 2005. This law for the first time introduced basic concepts and requirements for developer's activities, defined the requirements for the form of an equity participation agreement, so each equity participation agreement was obligated to be registered in the federal state cadaster and cartography service.

Later, this law was frequently amended and adjusted, which indicates the state's desire to regulate this sphere. Thus, in 2010 the government continuing the fight against rogue developers, introduced amendments to 214-FZ and the new law "On State Registration of Rights to Real Estate and Transactions Involving it". In 2012, insurance of civil liability of a developer for improper performance of obligations or its bankruptcy was introduced and it replaced the voluntary insurance of citizens to protect themselves from the risks of buying a home under an equity agreement. The reason for such actions was the lack of protection of equity holders by insurance. The other changes in the legislation governing shared-equity construction are the following: Federal Law "On Amendments to the Federal Law "On Participation in the Shared-Equity Construction of Apartment Buildings and Other Real Estate Objects and on Amendments to Certain Legislative Acts of the Russian Federation", certain Legislative Acts of the Russian Federation of July 3, 2016 No. 304-FZ and the Federal Law "On the Public Law Company for the Protection of the Rights of Citizens - Participants in Share-Equity Construction under Bankruptcy of developers and on amendments to certain legislative acts of the Russian Federation” of July 29, 2017 No. 218 FZ.

\section{Discussion}

The leading role of the construction sector is considered top-priority for the development of other sectors of economic activity and consolidation of social stability. The development and competitiveness of the country's economy largely depends on the effectiveness of the 
construction complex functioning. For a clearer understanding of the importance of this industry, it is worth mentioning the volume of construction work in monetary terms (Figure $1)$.

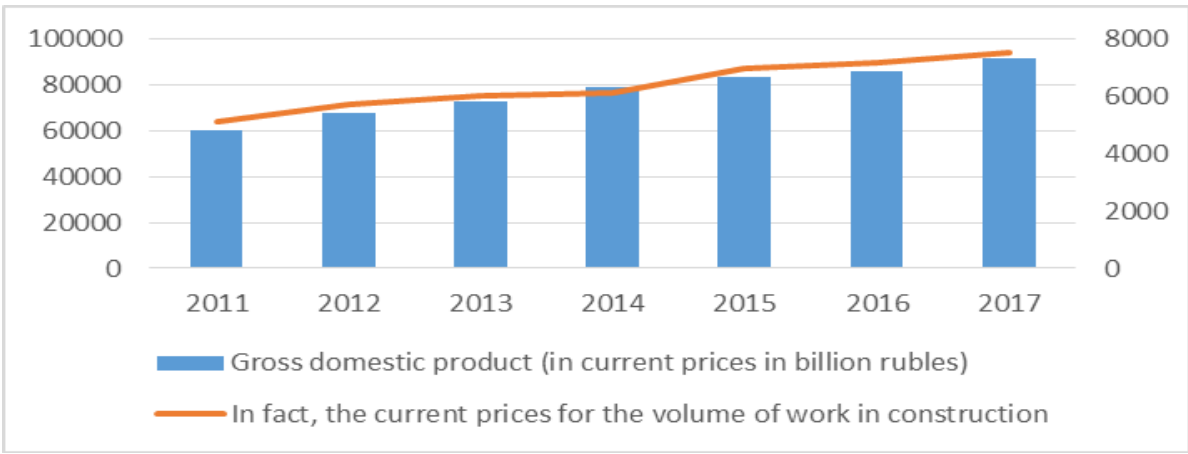

Fig.1.The volume of works performed by "Construction" economic activity in the Russian Federation for 2013-2017 (in billion rubles)

According to the Ministry of Finance, the volume of revenues of the federal budget for 2016 amounted to $13,738.5$ billion rubles. Comparing with the data on the scope of work for 2016, which amounted to 7545.9 billion rubles, it can be concluded that the construction industry accounts for almost half of the federal budget of the country. According to the Federal State Statistics Service, the gross domestic product for 2017 in current prices amounted to 92037.2 billion rubles, in 2016 prices it amounted to 87480.1 billion rubles. The share of the construction industry was $12.19 \%$ and $11.59 \%$ of the gross domestic product, respectively.

The participation of investors' funds in construction, particularly in erecting residential buildings, has become a common form of investing. Participants or equity holders of such investments contribute their own funds into creating a housing project. A legal entity (a developer) in its tern undertakes to implement the project, in which equity holder's funds were invested, therefore, participants being investors acquire ownership of a part of real estate in the form of housing or more favorable conditions for purchasing an apartment in designed and erected building if there is a permission for commissioning.

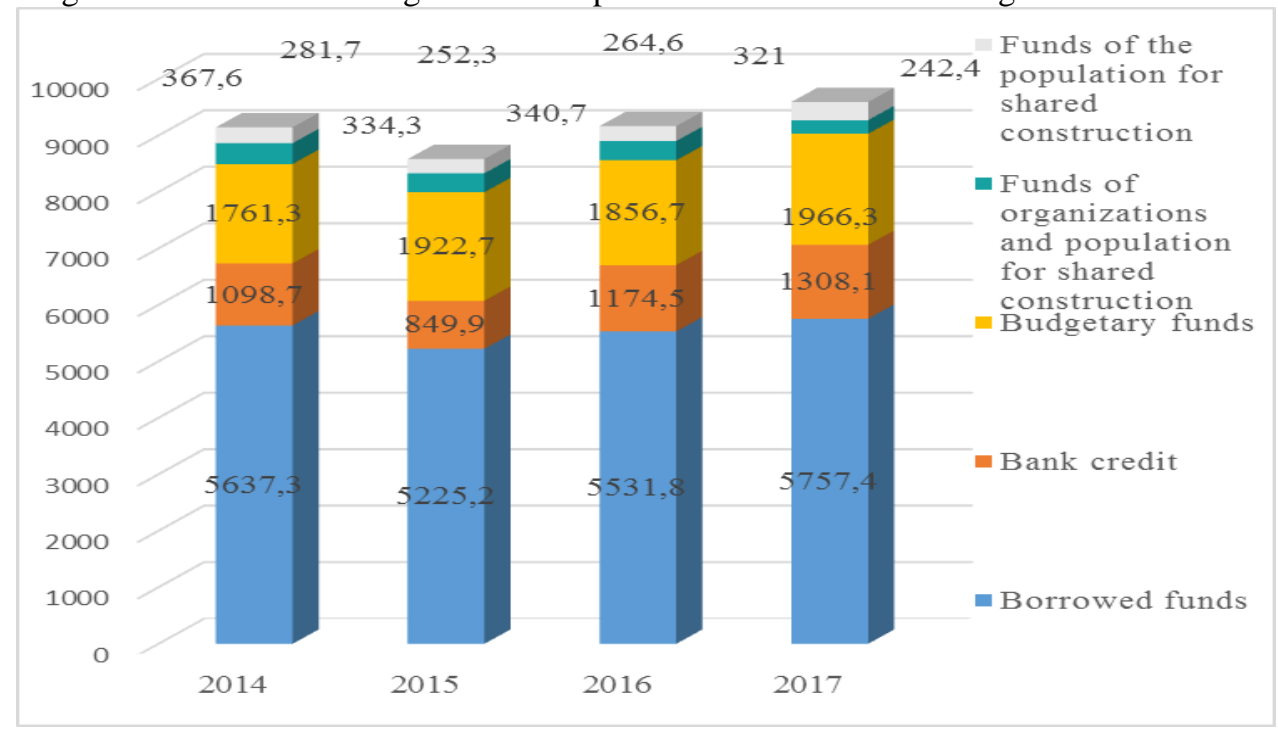

Fig.2. Investments into fixed capital by sources of financing for 2014-2017 (in billion rubles) 
When analyzing the data (Figure 2), the population's funds constitute a small part (only $4.71 \%$ ) of the total amount of total attracted investments for 2014-2017. The most part is the investments from the budget and bank loans. The fall in investment in 2015 is due to the sanctions against Russia, a fall in prices for oil, the continuing currency crisis, rising inflation, a weakening of the country's economy and a decrease in exports. This was the main reason for the decrease in investment of funds among the population and companies of the country. This is also evidenced by government support by increased investment in construction. As the investment crisis was overcome, and unprecedentedly low inflation was established, in 2016 investment growth was observed. When comparing attracted funds of organizations and of the population, the prevalence of citizens' share of investment capital is observed (averagely 76.32\%) (Figure 3), which indicates a high level of interest in the construction of various objects in shared-equity construction.

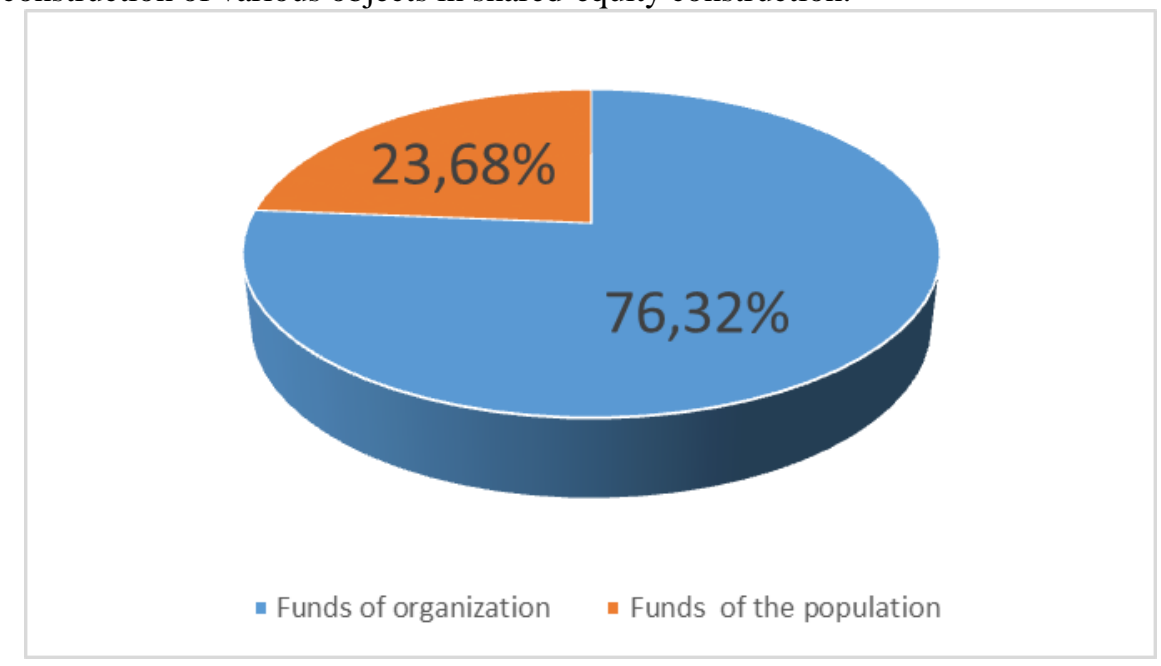

Fig.3.Ratio of participation share of funds of organizations and citizens in shared-equity construction

Despite the positive situation in the investment sphere, there are also negative factors affecting citizens of the country and their financial status. Cases of using schemes of multiple apartment sales have become frequent. Legal proceedings always last long, while no one returns money to equity holders without a court order. This adversely affects the financial condition of an equity holder.

On the basis of the conducted studies and their analysis, the shortcomings of the existing system of activities in the shared-equity construction were revealed, as well as of the proposed system of escrow accounts, which is introduced from July 1, 2019.

There are various fraud schemes, including the following:

1. Signing a preliminary sale and purchase contract instead of a contract of equity participation. Such a contract is aimed to avoid the law on shared-equity construction. This contract does not contain deadlines and obligations for a developer, moreover, it does not guarantee completing of a facility construction.

2. Buying a bill, signing a contract with a bank, not a developer, depositing funds into a deposit account, as well as entering into a contract with an intermediary, such as a contractor or supplier of building materials. Part 1 of Article 1 of the Federal Law No. 214FZ "On Participation in the Shared-Equity Construction of Apartment Buildings and Other Real Estate Objects and on Amendments to Certain Legislative Acts of the Russian Federation" states: "The law regulates relations connected with raising funds from citizens and legal entities...". And in Part 1 of Article 5 of the Federal Law, the contract price 
determines the amount of monetary funds that are to be paid by a participant in shared construction for the construction of a shared construction object. From this we can conclude that only monetary form of payment is provided. So when deciding to pay in non-monetary form, an unscrupulous developer can use this flaw to circumvent the requirements of the law. This may lead to deprivation by shareholders of rights and guarantees provided for by 214-FZ and, therefore, cannot claim appropriate protection.

3. Double or multiple sale of housing to real estate equity holders or potential buyers. The company sells an apartment through an intermediary's firm or by itself, hiding the fact that this apartment already belongs to an owner. If there is a share agreement with an equity holder, then this document can be submitted with a delay or intentionally not be submitted. In this case, an equity holder may not receive the living space, yet return invested money.

4. Signing the agreement under the absence of permits for construction from a developer which means that the developer offers to sign a contract for the construction of a facility that is not going to be built. This situation may include the absence of developer's documents confirming the right to lease the land. The agreement with an equity holder can be concluded in the form providing for the minimization of costs and risks for a developer.

The absence of any references to a share participation contract in the Civil Code of the Russian Federation is also worth to be mentioned. This fact can influence the solution of complex legal issues in the field of shared construction, for example the situation when in spite of a share participation contract, another different yet alike agreement with an equity holder was made.

There are also various ways to extract funds of equity holders:

1. Collection of co-payments from co-investors, which was not provided for in the equity construction contract.

2. The developer intentionally delays deadlines for commissioning a residential building or prolongs the period of construction. This method is used to obtain additional financial resources from equity holders or to implement funds in other projects, for example, to complete the construction of a building that was supposed to be commissioned a while ago. In this case, the chance not to get housing is much more than in the first case. Also, if an equity holder took a loan or a mortgage to conclude an equity construction contract, his costs would double, since, despite he is able repay the loan, he will not receive the promised apartment.

3. The use of materials or application technologies that do not meet the quality standards and standards required by the legislator, in other words, poor-quality resources for the construction of a residential building. In the documentation of the developer, all materials may meet the required standards, but in fact they are not. The difference, with this method of extracting benefits, between the funds received and the expenditure will pass into the hands of the fraudster. This development may entail in addition to the cost of numerous repairs, which are associated with the occurrence of various kinds of problems due to poor quality materials, for example, but also a direct threat to the buyer's health.

In analyzing the proposed system, which will become mandatory for all developers in the field of shared-equity construction, a number of shortcomings were identified, for instance:

1. The occurring of unfavorable situation with equity holders and developers, when negative factors appear in the activities of a bank where escrow account is located. In addition, the possibility of using equity holders in banking is not stipulated. If the bank is able to use money of equity holders in its economic activities, then there is a risk of unprofitable financing. With the appearance of negative factors in the bank, with the deterioration of its economic situation, the situation may be unfavorable for both equity holder and developer. In the event of bank failure, equity holders may receive only a part of the invested money back, while having unrecovered debts to the developer. 
2. It is not known whether the bank will take fee for keeping funds in the account and who will be responsible for paying this reward. It remains unclear also the issue of escrow accounts. The equity holder puts the money in the bank box, and the developer operates from the funds received. The bank, carrying out the function of storing funds, can take a reward. This fee will be borne by the shareholders, since their funds are being deposited. Also, when issuing funds to the developer in a loan, the bank can assign a certain percentage to the borrowed funds. As a result, these percentages can also become a problem of the shareholder or the buyer of housing, since the developer can raise the price of housing.

3. The possibility of price rising for residential space, which is unprofitable for the buyer of the property. The reasons for the increase in prices per square meter of living space will be a decrease in competition in the market, and, consequently, a decrease in supply. Cancellation of shared-equity construction since July 1, 2019 is leading to the increase in prices, which is not beneficial to buyers. The transition to the complete abolition of shared-equity construction started in July 2018 and lasted until June 30, 2019. Now all developers wishing to raise funds from citizens are required to build residential buildings not at the expense of developers, but for their own funds or funds attracted from outside, for example, by getting a loan. Another reason for the rise in housing prices is the increased influence of the large companies represented in the construction market. Medium and small construction organizations will have to unite to maintain their positions in the market or even disappear from the market of shared-equity construction, which will also reduce the number of competitors. Due to the reduction in the number of competing companies, it will be possible to increase prices, it also opens the possibility to cancel any stimulants for product promotion, since the demand for housing in Russia is high and the supply has decreased. This situation may also lead to the attraction of large foreign construction organizations to the Russian market, which may further cause the capital outflow from the country and create a threat to the economic security of the entire state. Another scenario is that the increase in prices will lead to a fall in consumer demand for the buildings being erected, which will cause the fall in the volume of the construction industry and the further possible crisis in the construction sector and related industries.

4. If it is impossible for developers who have taken loans for construction to continue their activities, complications with banks and equity holders may occur. The Central Bank of Russia explains that new accounts will not bear the risks associated with troubled and unscrupulous developers, since debiting funds from shareholders' accounts is possible only when the property is put into operation. In case of occurrence of negative circumstances with the developer, and the appearance of a circumstance of the impossibility to continue its activities, it may remain unpaid debts that need to be repaid. This scheme can also be risky for shareholders, since their money is guaranteed only by the reputation and responsibility of the bank. After all, if a developer opens several credit accounts in a bank and is unable to complete construction on objects, then such a situation may endanger not only the financial position of the bank, but also the equity holders.

Protection of escrow accounts from the risks associated with banks is also provided. When depositing funds into a bank account, funds are insured under share participation agreements at the expense of the Deposit Insurance Agency for up to 1.4 million rubles. Further it is planned to increase the amount of insurance of each deposit in the amount of up to 10 million rubles. The conclusion of the contract of shared construction is carried out when signing a tripartite agreement between the shareholder, the developer and the bank. The bank in which it will be possible to make a similar operation is approved by the Central Bank. The approval takes place in accordance with the verification of the reliability of the bank and its possible degree of bankruptcy. 
In case of non-compliance with the terms of a share-equity construction agreement by an unfair developer, the real estate investor will have the right to terminate this agreement, so the funds invested by it will be returned. This is one of the positive factors indicating the increase in the security of equity holders' funds. However, a situation may arise when the price of housing and, accordingly, the investment of a shareholder will exceed the amount of the insurance premium. Then all the measures taken to protect equity holders' money may simply fail, so that a holder may lose part of the invested funds.

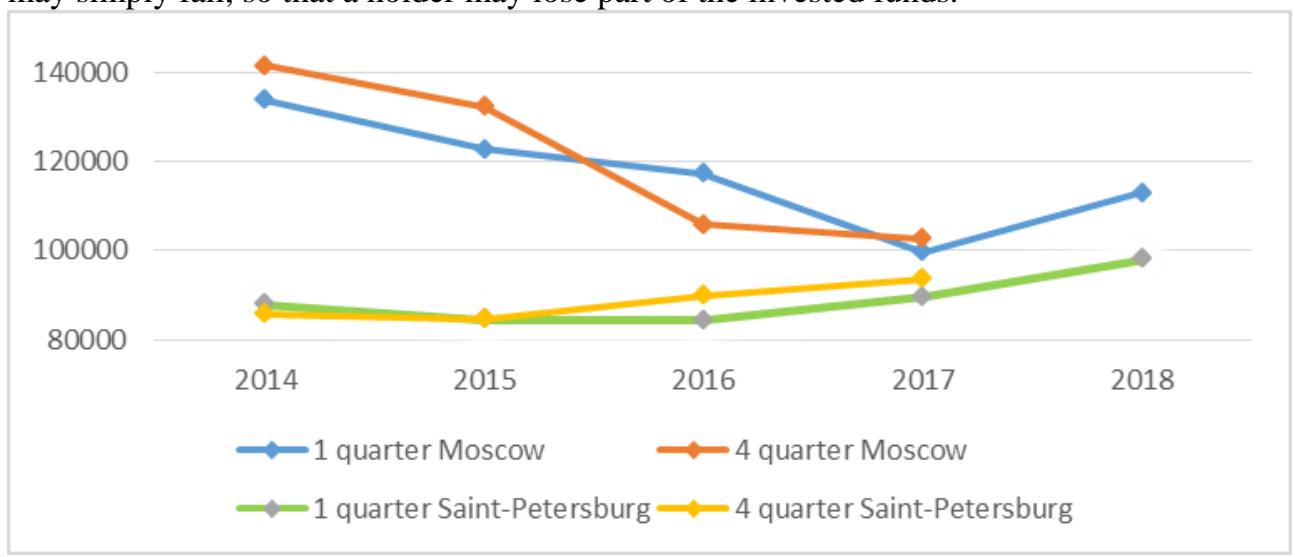

Fig.4. Average price in rubles per $1 \mathrm{~m}^{2}$ of the total area of apartments on the primary housing market, medium-quality apartments in the cities of Moscow and St. Petersburg

The data of average prices per square meter on the primary housing market in Moscow and St. Petersburg (Figure 4) suggest a similar trend in price changes. It can be concluded that the fall in prices is associated with the continuation of sanctions against Russia and the currency crisis in the period from 2014 to 2016. The temporary fall in the ruble exchange rate in 2014 forced citizens to invest in sustainable, reliable assets, that is in real estate, which subsequently increased the demand for housing, and as a result, prices started rising. When comparing the prices of the first and fourth quarters of all the considered five years, it can be concluded that the primary housing market of St. Petersburg is more stable compared to Moscow, since the rise in housing prices in St. Petersburg began in the first quarter of 2017, the level of price drops is not exceeded 4\%, while in Moscow there is a gradual decline in prices until 2018. This suggests that the entire amount of invested funds may not be covered by deposit insurance. The standard area in St. Petersburg for a person is $9 \mathrm{~m}^{2}$, at a price for 2018, the cost of an apartment is 1473089.4 rubles, this amount is almost completely covered by insurance, but when purchasing a living area that is more than $9 \mathrm{~m}^{2}$, the insurance will not be able to compensate lost funds.

5. Another negative aspect is a complication of the conditions for entering the market of shared-equity construction. Tougher conditions will not affect large developers, but will influence ones who have just entered the construction market. This in turn will lead to a decrease in the competition level in this market, which may adversely affect the development of the construction industry as a whole. In addition to the fact that no new business entities will appear, small companies may leave, which coupled with the increase in demand and small supply will provoke a sharp and significant increase in prices per square meter of living space.

Another controversial point lies in fact that when creating a deposit, equity holders transfer funds for a period of construction work to a bank, which in turn can use that money in its financial activities. A bank can return funds to equity holders any time, since there is a reserve fund. Thus it can be concluded that a bank uses funds of equity holders without paying any compensation for the funds invested by them, and receives interest of the used 
funds as a profit, without giving part of the profit to an equity holder, although the funds for a profit belong to a holder. At the same time there is a risk that the use of funds of equity holders can lead to financial insolvency of a bank, which can expose equity holders to losses and inability of the developer to continue the construction activities.

\section{Conclusion}

The construction industry in Russia is growing every passing year. The sharp increase of companies' inability to service debt obligations to a bank may lead to real estate alienation in favor of creditors (banks or credit organizations). This can cause the decline in real estate prices, increase in interest rates and the number of debtors just as it was in 2007-2008, which can lead to the bankruptcy of banks and necessitate the introduction of tough governmental regulatory measures. One of the lessons that can be learned after the mortgage crisis of the United States of America is the introduction and active use in the affordable housing construction sphere of mortgage institutions that are simple and transparent for the regulation and supervision. The mechanism of state regulation and support (subsidies) of the savings accumulation system used to provide benefits to the potential buyer of residential property, not to construction organizations or any intermediaries, for instance, to credit companies. A vivid example is the diligently elaborated system of housing savings in Germany. This system is based on the attraction of savings by the borrower according to the principle of deposit accumulation. Governmental support is provided only at the stages of primary funds accumulation and of repayment of a loan for residential space, which expands the affordability of housing, since the funds are relatively cheap and allow providing affordable loans for purchasing apartments.

Based on the research, the authors analyzed the current situation in the shared-equity construction market in the Russian Federation, revealed shortcomings in the legislation and realworld effects, identified the risks of new conflicts caused by changes in legislation concerning shared-equity construction relations and suggested certain ways to prevent them.

\section{References}

1. Resolution of the government of the Russian Federation of 17.12.2010 № 150 "On the implementation of certain measures of the state program of the Russian Federation" Providing affordable and comfortable housing and communal services to citizens of the Russian Federation".

2. Federal law of Russian Federation No. 214-FZ of 30.12.2004 "On participation in shared construction of apartment buildings and other real estate objects and on amendments to certain legislative acts of the Russian Federation".

3. V. Rozhkov, Russian Journal of Entrepreneurship. 16(19) (2015) (in Russian). DOI: 10.18334/rp.16.19.1970.

4. K.B. Dobrova, Russian Journal of Innovation Economics. 7(4) (2017) (in Russian). DOI: 10.18334/vinec.7.4.38559.

5. S.A. Chernyakova, Journal: Services in Russia and abroad. 8 (9) (2014). DOI: $10.12737 / 10806$ 